\title{
1. Intellectual property rights as 'investments' under international investment agreements
}

\section{DEFINING THE NOTION OF 'INVESTMENT'}

Because IPRs represent in today's economies a dominant asset for companies established in technologically advanced countries, the necessity for investors in IPRs to benefit from the protective regime of IIAs is essential. These protections also appear indispensable for investments that do not primarily consist in IP as, regardless of the nature of the invested assets, IPRs are likely to constitute part of the global investment operation, whether taking the form of trade secrets, trade names or tacit know-how.

Most IIAs provide for a definition of the term 'investment' under which IPRs are, most of the time, included. While the vast majority of IIAs include IP under their scope of application, there is however a global lack of standardization concerning the way in which IPRs are covered by model treaties; a lack of coordination that provides fertile ground for disputes. ${ }^{1}$

The coverage of IPRs under IIAs can indeed be done in several ways. First, IIAs can include IPRs under their scope by explicitly enumerating the kind of IP that is covered under the agreement. This first method, used by the vast majority of BITs, ${ }^{2}$ leaves no room for doubt and insures a high degree of legal certainty. For example, the German 2008 Model BIT includes in the listed items that should be considered as investments:

1 Rachel A. Lavery, 'Coverage of Intellectual Property Rights in International Investment Agreements: An Empirical Analysis of Definitions in a Sample of Bilateral Investment Treaties and Free Trade Agreements', 6:2 T.D.M. 1 (August 2009), at 13.

2 See Christoph Schreuer with Loretta Malintoppi, August Reinisch and Anthony Sinclair, The ICSID Convention: A Commentary (2nd edn, Cambridge University Press, 2009) ('The list of typical rights [covered by BIT definitions of 'investment'] usually includes ... intellectual and industrial property rights', at $123, \mathrm{n} 140)$. 
(d) intellectual property rights, in particular copyrights and related rights, patents, utility-model patents, industrial designs, trademarks, plant variety rights;

(e) trade-names, trade and business secrets, technical processes, know-how, and good-will ... .

Another example can be found in the French 2006 Model BIT encompassing under the term 'investment':

1. . . every kind of asset, such as goods, rights and interests of whatever nature, and in particular though not exclusively ...

d) intellectual, commercial and industrial property rights such as copyrights, patents, licences, trademarks, industrial models and mock-ups, technical processes, know-how, trade names and goodwill . . .

A similar drafting can be found in the Chinese 1997 Model BIT that includes under the definition of the term 'investment':

(d) intellectual property rights, in particular copyrights, patents, trademarks, trade-names, technical process, know-how and good-will . . .'

Some BITs may, however, be less precise by broadly providing for 'intellectual property rights' under the term 'investment' without listing each specific type of IP that should be included as such. ${ }^{6}$ Investment treaties

3 Treaty Between the Federal Republic of Germany and

Concerning the Encouragement and Reciprocal Protection of Investments, available at http://www.italaw.com/ (accessed 27 January 2014).

4 Draft Agreement Between the Government of the Republic of France and the Government of the Republic of . . . on the Reciprocal Promotion and Protection of Investments, available at http://www.italaw.com/ (accessed 27 January 2014).

5 Third Chinese Model BIT, Agreement Between the Government of the People's Republic of China and the Government of on the Promotion and Protection of Investments, in Norah Gallagher and Wenhua Shan, Chinese Investment Treaties: Policies and Practice (Oxford University Press, 2009), Appendix, at 427-431.

6 See e.g. the United States-Bahrain BIT (Treaty Between the Government of the United States of America and the Government of the State of Bahrain Concerning the Encouragement and Reciprocal Protection of Investment, signed at Washington on 29 September 1999, entered into force 30 May 2001, available at http://unctad. org/ (accessed 27 January 2014)), article 1. For other similarly succinct definitions, see most of the UK's investment treaties dated in the 1970s and 1980s (e.g. the UK-Antigua and Barbuda BIT (Agreement between the Government of the United Kingdom of Great Britain and Northern Ireland and the Government of Antigua and Barbuda for the Promotion and Protection of Investments, signed 12 June 1987, entered into force 12 June 1987, available at http://unctad.org/ (accessed 27 January 
may use an even broader terminology by targeting under the notion of 'investment' 'every kind of asset'7 or, circularly providing for an openended coverage of 'every kind of investment's without explicitly listing IP within their scope at all. ${ }^{9}$

Confronted with such broadly drafted provisions encompassing under their scope a potentially wide range of assets, article 31 of the Vienna Convention on the Law of Treaties (VCLT) ${ }^{10}$ appears particularly relevant. According to article 31(1)-(2) of the VCLT, as applied to the matter at hand, the interpretation of the notion of investment does not need to be limited to the 'exact wording of the treaty, but may also take into account the object and purpose of the treaty and its context'. ${ }^{11}$ Moreover, by application of

2014)), the Korea-United Kingdom BIT (Agreement between the Government of the Republic of Korea and the Government of the United Kingdom of Great Britain and Northern Ireland for the Promotion and Protection of Investments, signed 4 March 1976, entered into force 4 March 1976, available at http://unctad. org/ (accessed 27 January 2014)) or the United Kingdom-Yemen BIT (Agreement between the Government of the United Kingdom of Great Britain and Northern Ireland and the Government of the Yemen Arab Republic for the Promotion and Protection of Investments, signed 25 February 1982, entered into force, 11 November 1983, available at http://unctad.org/ (accessed 27 January 2014)).

7 UK-Ecuador BIT (Agreement between the Government of the United Kingdom of Great Britain and Northern Ireland and the Government of the Republic of Ecuador for the Promotion and Protection of Investments, signed 10 May 1994, entered into force 24 August 1995, available at http://unctad.org/ (accessed 27 January 2014)), article 1.

8 Netherlands-Brazil BIT (Agreement on Encouragement and Reciprocal Protection of Investments between the Kingdom of the Netherlands and the Federative Republic of Brazil, signed 25 November 1998, available at http:// unctad.org/ (accessed 27 January 2014)), article 1(a).

9 See also e.g. the France-Singapore BIT (Accord entre le Gouvernement de la République française et le Gouvernement de la République de Singapour sur l'encouragement et la protection des investissements, signed 8 September 1975, entered into force 18 October 1976, available at http://unctad.org/ (accessed 27 January 2014)), article 1 ('les avoirs de toute nature') or the Netherlands-Pakistan BIT (Agreement on Economic Cooperation and Protection of Investments between the Kingdom of the Netherlands and the Islamic Republic of Pakistan, signed 4 October 1988, entered into force 1 October 1989, available at http://unctad.org/ (accessed 27 January 2014)), article 1(a) ('every kind of goods, rights, and interests of whatsoever nature').

10 Vienna Convention on the Law of Treaties (hereinafter 'VCLT'), adopted on 22 May 1969, 115 U.N.T.S. 331, 8 I.L.M. 679.

11 Bertram Boie, 'The Protection of Intellectual Property Rights through Bilateral Investment Treaties: Is there a TRIPS-plus Dimension?', NCCR Trade Working Papers No. 2010/19 (November 2010), available at http://www.wti.org/ (accessed 27 January 2014), at 11. 
article 31(3)(c) of the VCLT, according to which the interpretation should take into account 'any relevant rules of international law applicable in the relations between the parties', these broad provisions could require turning to other sources in order to interpret the treaties. This norm has indeed been described as a 'general principle of treaty interpretation, namely that of systemic integration within the international legal system ... [that] has the status of a constitutional norm . . . [and] serves a function analogous to that of a master-key in a large building'. ${ }^{12}$ As such, a treaty should refer to these principles for all questions it does not expressly resolve. ${ }^{13}$

By application of these rules of interpretation, such open-ended terminologies, often followed by an illustrative, non-exhaustive list of properties covered by the treaty at stake, illustrate the flexible definition often given to the term 'investment'. It is from this perspective that the use of such broad language 'gives reason to assume that a general recognition of BITs covering intangible property exists'. ${ }^{14}$ This assumption arises from the fact that for some time it has clearly been established that such intangible assets constitute a form of property as a consequence of the consecration of their protection through several international conventions. ${ }^{15}$ Moreover, this trend has been confirmed in the field of IIAs, as the very

12 Campbell MacLachlan, 'The Principle of Systemic Integration and Article 31(3)(c) of the Vienna Convention', 54 Int'l \& Comp. L. Q. 279 (2005), at 280-281.

13 Franco-Mexican Commission (Verzijl, President), George Pinson (France) v. United Mexican States, 19 October 1928, 5 R.I.A.A. 327 (1952), at 422, para. 50. See also generally on the interpretation of IIAs, Anne van Aaken, 'Fragmentation of International Law: The Case of International Investment Protection', University of St. Gallen Law School - Law and Economics Research Paper Series, Working Paper No. 2008-1 (2008), available at http://papers.ssrn. com/sol3/papers.cfm?abstract_id $=1097529$

14 Bertram Boie, op. cit., at 8.

15 See e.g. Berne Convention for the Protection of Literary and Artistic Works, 9 September 1886, as revised at Paris, 24 July 1971, 828 U.N.T.S. 221; Paris Convention for the Protection of Industrial Property, 20 March 1883, as revised at Stockholm, 14 July 1967, 21 U.S.T. 1538, 828 U.N.T.S. 305. It is worth mentioning that these conventions were drafted and entered into force before the ICSID Convention. However, the consecration of the importance of IPRs has also been explicitly set forward more recently, such as in the TRIPs' Preamble '[r]ecognizing that intellectual property rights are private rights ... [and] the underlying public policy objectives of national systems for the protection of intellectual property' (at (e)). Reference to IPRs was also a common feature of US Friendship Commerce and Navigation (FCN) Agreements that were negotiated as early as 1778, with the Treaty of Amity and Commerce between the United States and France, before the expansion of BITs. Regarding IPRs, it is noteworthy that the FCN treaty between the US and China that was negotiated in 1903 included 
first BIT, concluded between Pakistan and Germany in 1959, followed this logic by explicitly encompassing IPRs under the notion of 'investment'. ${ }^{16}$ Far from being a novelty, this tendency was later confirmed through an extensive range of BITs including explicit references to IPRs; ${ }^{17}$ sometimes even in their preamble, such as the 1999 US-Turkey BIT which recognizes 'the importance of providing adequate and effective protection and enforcement of intellectual property rights and of adherence to intellectual property conventions'. ${ }^{18}$ Accordingly, it leads to the assertion that IP is 'so clearly recognized by international instruments as a form of property ... that the default presumption must be that it would be included in any ... broad definitio[n] of investment'. ${ }^{19}$

Such an outcome should not, however, be taken for granted, as was illustrated by the major debate that arose during the negotiations of the Multilateral Agreement on Investment (MAI), in which several countries argued for the exclusion of IP from the definition of investment. ${ }^{20}$ Such an assertion can, moreover, be questioned in light of the numerous issues related to the coverage of IP under the notion of 'investment'.

copyright protection (Lahra Liberti, 'Intellectual Property Rights in International Investment Agreements: An Overview', 6:2 T.D.M. 1 (2009), at 6).

16 Pakistan-Germany BIT (Pakistan and Federal Republic of Germany Treaty for the Promotion and Protection of Investment, signed 1 December 1959, available at http://www.iisd.org/ (accessed 27 January 2014)), article 8(1)(a): 'The term "investment" shall comprise capital brought into the territory of the other Party for investment in various forms in the shape of assets such as ... property rights, patents and technical knowledge.'

17 See supra.

18 Treaty between the United States of America and the Republic of Turkey Concerning the Reciprocal Encouragement and Protection of Investments, signed 3 December 1985, entered into force 18 May 1990, available at http://unctad.org/ (accessed 27 January 2014). As emphasized by Lahra Liberti, '[a]lthough not mandatory in character, the provisions of a treaty preamble deserve particular consideration for the purpose of treaty interpretation as part of the context under Article 31(2) of the Vienna Convention on the Law of Treaties' (Lahra Liberti, op. cit., at 6).

19 Julian Davis Mortenson, 'Intellectual Property as Transnational Investment: Some Preliminary Observations', 6:2 T.D.M. 1 (August 2009), at 5-6. For an exhaustive study on the interpretation of investment treaties see Rudolf Dolzer and Christoph Schreuer, Principles of International Investment Law (Oxford University Press, 2008), at 31 et seq.

20 The sensitivity of the issue focusing on the inclusion or exclusion of IP in the definition of 'investment' was expressed in the report to the negotiating group on intellectual property. See in this regard OECD (1997), 'Report to the Negotiating Group on Intellectual Property', Negotiating Group on the Multilateral Agreement on Investment (MAI), 26 March 1997, DAFFE/ $\operatorname{MAI}(97) 13$, at nos 2 and 4. 


\section{ISSUES RELATED TO THE COVERAGE OF INTELLECTUAL PROPERTY RIGHTS UNDER THE NOTION OF 'INVESTMENT'}

If it is generally assumed that IP qualifies as an investment under IIAs, whether expressly cited in the agreement or included under a general definition of 'investment', several issues are still susceptible to arise that could proscribe IP investors from benefiting from the protections of the agreement at stake.

The first issue that needs to be stressed focuses on the eventual other requirements in IIAs that need to be met by IPRs (or other assets) in order to qualify as investments.

Indeed, in order to be covered by IIAs, even if expressly included under the definition of 'investment', IPRs must fulfil the other treaty requirements and present the characteristics of an investment. This prerequisite is often set forward by the treaty itself, such as the US 2012 Model BIT that states in its first article that:

\footnotetext{
'investment' means every asset that an investor owns or controls, directly or indirectly, that has the characteristics of an investment, including such characteristics as the commitment of capital or other resources, the expectation of gain or profit, or the assumption of risk. Forms that an investment may take include:

(f) intellectual property rights . . .
}

According to this provision, the mere possession of IPRs or the fact that IP is involved in a commercial operation in a given Host Country does not automatically qualify it as an investment. Indeed, if the IP at stake 'is not applied in a host country in a substantive way in its business operations ${ }^{21}$ and is not committed, for example, to an investment with expectation of gain or without any risk component, it likely will not qualify as an investment. ${ }^{22}$

Consequently, notwithstanding the general presumption according to which IP is covered under a broad definition of 'investment' covering

\footnotetext{
21 Bertram Boie, op. cit., at 9.

22 However, it is important to note that, as emphasized by Rachel A. Lavery, there are 'other potentially applicable jurisdictional prerequisites to coverage beyond merely falling within the definition of "investment". These may include compliance with the definition of "investor", citizenship issues, timing of the investment and existence of an investment authorization' (Rachel A. Lavery, op. cit., at 3).
} 
'every kind of asset', ${ }^{23}$ the fact that IP is expressly mentioned or even that the different types of IP are listed in the treaty will not suffice to guarantee that a particular IP qualifies as an investment under the treaty at stake. A broad legal and economic analysis of the IP will be required.

In addition, IIAs may require that the investment at stake has a financial value, which represents an important condition when rights are at stake, and especially IPRs. Indeed, where the investment at stake involves, for example, a licensing contract of trade secrets but these intangible assets have already been disclosed either in the Home or Host Country of the licensing foreign company, they might be considered as part of the public domain, and thus devoid of any financial value and unable to qualify as investment under domestic law.

The requirement that the invested asset has a financial value is indeed important, especially given the territorial nature of most IPRs, as it:

creates a link with domestic law, since it is to a large extent the rules of domestic law that determine whether or not there is a financial value. In other words, value is not a quality deriving from natural causes but the effect of legal rules which create rights and give protection to them. ${ }^{24}$

The link with domestic law is especially significant when IP is at stake as several IIAs may require IPRs to be granted in accordance with the legal regime of the Host State, ${ }^{25}$ which is of particular importance in regard to the territoriality principle associated with certain IPRs.

Such a prerequisite is particularly important when patents are at stake, for example, as they are embedded in a strong territorial logic:

See supra, notes 12 to 14.

24 Stockholm Chamber of Commerce (SSC), Mr. X (United Kingdom) v. The Republic (in Central Europe), Final Arbitral Award, rendered in 2003, Case 49/2002, 2004:1 Stockholm Arbitration Report 141 (2004), at 158. It is important not to forget, as noted by the ICSID arbitral tribunal in Salini et al. v. Morocco (ICSID, Salini et al. v. Morocco, Decision on Jurisdiction, 23 July 2003, ICSID Case No. ARB/00/4, 42 I.L.M. 609 (2003)), that a requirement of compliance with domestic law 'refers to the validity of the investment and not to its definition' (at para. 46, emphasis added). For the question of the applicable law, see infra.

${ }_{25}$ See e.g. the India-Ghana BIT (Agreement between the Government of the Republic of India and the Government of the Republic of Ghana for the Reciprocal Promotion and Protection of Investments, signed 18 August 2002, available at http://unctad.org/ (accessed 27 January 2014)); the GhanaBenin BIT (Agreement between the Government of the Republic of Ghana and the Government of the Republic of Benin for the Promotion and Protection of Investments, signed 18 May 2001, available at http://unctad.org/ (accessed 27 January 2014)), Article 1(iv). 
patents are granted by countries and are limited to the territory of the state at stake. Consequently, a patent granted in a given country will not necessarily be recognized in other countries, ${ }^{26}$ mainly as a result of the fact that countries do not necessarily share the same conditions for a technical invention to be protected by a patent: the inventor will only be granted a patent over its invention if its application is successful in a given jurisdiction. ${ }^{27}$

This territorial logic ${ }^{28}$ potentially represents an important challenge in the field of IPRs investments, as a given invention, even if protected by a patent in the Home Country of the investor, may not qualify for a BIT protection until the investor is granted a patent for its invention in the Host Country. In such a scenario, the invention patented in the investor's Home Country would not acquire the status of 'investment' under the relevant BIT until the authorities of the Host Country grant the IPR to the investor for its invention.

Under these circumstances, the investor would face a significant danger by being at the mercy of the Host State, which would lead to a situation undermining the rationale behind the existence of the corpus of rules and principles of international investment law. Indeed, international investment law aims at guaranteeing the protection of investors when contracting with a state and tries to avoid as much as feasible the possibility for Host States to act in a discretionary manner by regulating the investor-Host State relationship under agreements such as BITs. The situation in which the protection of an investment under a BIT would depend on the Host State's authorities' decision to validate and grant a patent within the state's border would thus put the investor in a delicate and dangerous position. Moreover, in light of the lack of legal certainty, such a hypothesis would 'constitute an unreasonable hindrance to investments' ${ }^{29}$

An alternative and more investor-friendly trend tends to argue for the protection of IP from the moment the inventor enters the application process for a domestic patent. From this viewpoint, as soon as the

\footnotetext{
${ }_{26}$ We should, however, note the fast evolution towards the creation of a unitary European patent.

27 The territoriality principle and the importance of domestic law deriving from it are also particularly important concerning (indirect) expropriation-related questions. For a detailed analysis of these issues, see infra Part II.

${ }_{28}$ It is noteworthy that the territorial logic at stake here is the territoriality of IPRs as opposed to the territorial logic of international investment law studied infra in Chapter 3.

29 Bertram Boie, op. cit., at 10.
} 
application process is engaged in the Host Country, the IP at stake, even if not - yet - protected by a right, is considered to be an integral part of the investor's property. ${ }^{30}$ This view has been adopted by several agreements, such as the United States-Jamaica BIT, providing for the protection of 'patentable inventions', ${ }^{31}$ which leads one to assume that 'the mere denial of granting a patent to a patentable invention could already constitute a violation of the investor's investment'. ${ }^{32}$

In a similar vein, the Canada-Argentina BIT ensures the protection of 'rights with respect to . . p patents', ${ }^{33}$ which could be 'intended to encompass not only granted rights but also applications'; ${ }^{34}$ a patent application could thus constitute a protectable asset under such a wording. Even broader in scope, the United States-Mongolia BIT protects 'inventions in all fields of human endeavor'. ${ }^{35}$

These formulations tend to encompass pending patents and, in the case of the US-Mongolia BIT, the protection may even arguably '[n]ot only . . . expand the types of inventions protected beyond those that are actually patented via a government body, but it seemingly eliminates patentability requirements such as novelty, non-obviousness, and utility'. ${ }^{36}$

30 For developments supporting this argument, see ECHR (Grand Chamber), Case of Anheuser-Busch Inc. v. Portugal, Judgement, 11 January 2007, Application no. 73049/01, Reports of Judgements and Decisions 2007-I, at para. 78.

${ }_{31}$ Treaty between the United States of America and Jamaica Concerning the Reciprocal Encouragement and Protection of Investment, signed 4 February 1994, entered into force 7 March 1997, available at http://unctad.org/ (accessed 27 January 2014), article 1(a)(iv).

32 Marie Louise Seelig, 'Can Patent Revocation or Invalidation Constitute a Form of Expropriation?', 6:2 T.D.M. 1 (July 2009) (the issue of expropriation will be studied in more details infra). The author further points out the need under such a formulation to determine what standards govern 'patentability' (at 3).

33 Agreement Between the Government of Canada and the Government of the Republic of Argentina for the Promotion and Protection of Investment, signed 5 November 1991, entered into force 29 April 1993, available at http://unctad.org/ (accessed 27 January 2014), article 1(a)(iv).

34 Carlos M. Correa, 'Investment Protection in Bilateral and Free Trade Agreements: Implications for the Granting of Compulsory Licenses', 26 Mich. J. Int'l L. 331 (Fall 2004), at 340. The author further states that under such a broad wording, "[t]hough it is clear that a still-unregistered invention is not an IPR, it may be argued that the application is, in any case, an "intangible property" as long as it is "owned" and can be assigned to third parties' (at 340).

35 Treaty between the United States of America and Mongolia Concerning the Encouragement and Reciprocal Protection of Investment, signed 6 October 1994, entered into force 4 January 1997, available at http://unctad.org/ (accessed 27 January 2014), article 1(1)(iv).

36 Rachel A. Lavery, op. cit., at 8. 
Finally, the Peru-Germany BIT goes one step further, encompassing within its scope 'technological knowledge and processes patented or not, technical documents and instructions', ${ }^{37}$

A further issue is that while some agreements may provide for compliance with domestic law as a validity requirement for assets to be considered as investments, '[n]ot all investment agreements are explicit in defining the concept of investment and the role of domestic law in determining the validity, scope and content of the rights over investment assets'. ${ }^{38}$ As a result, the broad definition of the notion of 'investment' in a given agreement can result in affording a higher protection to specific assets compared to the protection provided under domestic law for the same goods. Indeed, by application of public international law interpretation of treaties, ${ }^{39}$ terms of investment agreements 'should often be considered to have an autonomous meaning appropriate to the content of the specific treaty and to the issues it intends to regulate', ${ }^{40}$ and can thus be understood differently than the meaning attached to them in the context of domestic law. ${ }^{41}$

Such a gap between the content of the investment agreement and domestic law can also be explicit, as in the Ethiopia-Israel BIT, ${ }^{42}$ which

37 Convenio entre la República del Perú y la República de Alemania sobre Promoción y Protección Reciproca de Inversiones, signed 30 January 1995, entered into force 1 May 1997, available at http://unctad.org/ (accessed 27 January 2014), article 1(1)(d) (our translation). However, it is important to note that these developments do not necessarily apply to every type of IP. Copyrights, for instance, do not require to be registered in order to confer rights to the IP owner against third parties and ' $[\mathrm{t}]$ he lack of registration does not seem to affect the status of such rights as covered investments' (Carlos M. Correa, 'Bilateral Investment Agreements: Agents of New Global Standards for the Protection of Intellectual Property Rights?', GRAIN Reports (August 2004), available at http://www.grain.org/briefings/?id=186\#one/ (accessed 27 January 2014), at 9). Similarly, well-known trademarks that do not necessitate prior registration to benefit from a protection are not affected as far as their status of covered investments is concerned. It remains that the Host State may determine through domestic law 'the scope of the right over material protected by copyright [or well-known trademark]' (Ermias Tekeste Biadgleng, 'IP Rights Under Investment Agreements: The TRIPS-plus Implications for Enforcement and Protection of Public Interest', South Centre Research Paper no. 8 (August 2006), at 6).

38 Ermias Tekeste Biadgleng, op. cit., at 6.

39 See supra the developments concerning the VCLT.

$40 \mathrm{SCC}, \mathrm{Mr} . \mathrm{X}$ (United Kingdom) v. The Republic (in Central Europe), op. cit., at 156 .

${ }_{41}$ Such a situation may lead to the 'grey area where the IP rights recognised under the investment agreements are not available under domestic law' (Ermias Tekeste Biadgleng, op. cit., at 6).

42 Agreement between the Government of the Federal Democratic Republic of Ethiopia and the Government of the State of Israel for the Reciprocal Promotion 
includes under the definition of investment, geographic indications and plant-breeders' rights, despite the fact that Ethiopia is neither a member of the WTO nor a party to the International Union for the Protection of New Varieties of Plants (UPOV) ${ }^{43}$; in addition, at the time of the signing of the investment agreement, Ethiopia did not protect geographic indications and plant breeders' rights under its domestic law. ${ }^{44}$ It is clear that, in such circumstances, in case of conflict, tribunals would take into account the investment agreement's provisions without giving priority to domestic law. ${ }^{45}$

and Protection of Investments, signed 26 November 2003, entered into force 22 March 2004, available at http://unctad.org/ (accessed 27 January 2014), article $1(1)(d)$.

${ }_{43}$ The International Union for the Protection of New Varieties of Plants has been set up after the enactment of the International Convention for the Protection of New Varieties of Plants (hereinafter 'UPOV') of 2 December 1961, as revised at Geneva on 10 November 1972, 23 October 1978 and 19 March 1991, 815 U.N.T.S. 159.

44 Ermias Tekeste Biadgleng, op. cit., at 7.

45 See e.g. ICSID, Camuzzi International S.A. v. The Argentine Republic, Decision on Jurisdiction, 11 May 2005, Case No. ARB/03/2, available at http:// www.italaw.com/ (accessed 27 January 2014), at paras 56-57. 